\title{
General insurance marketing: a review and future research agenda
}

Dr Julie Robson

A version of this paper was published in the special 20th year edition of the Journal of Financial Services Marketing 2015, 20 (4) p282-291

\section{$\underline{\text { Abstract }}$}

The financial services sector is a huge and diverse industry comprising many different forms of organisations and product offerings. Yet, a review of past papers in the Journal of Financial Services Marketing (JFSM) reveals a heavy bias towards articles on banking, to the neglect of other equally important financial services categories. The purpose of this paper is to address this imbalance and to call for more research to be conducted in a wider range of financial services categories. In particular, general insurance is singled out as a category worthy of further research. Looking to the past, this paper reviews research published to-date on general insurance in the JFSM to establish a benchmark and explore theoretical contributions. Attention is then turned to the future to identify a research agenda for the general insurance sector going forward. 5 important themes are identified: trust, transparency and simplification, technology, HNW and Takaful.

Key Words: General insurance, trust, transparency and simplification, technology, HNW, Takaful,

\section{$\underline{\text { Introduction }}$}

The general insurance market is estimated to have a global value of $\$ 2,072.4$ billion and account for a significant proportion of the global financial services industry alongside banking and life insurance (Market Line, 2015). Despite its economic importance, it would appear that general insurance has failed to capture the attention of financial services marketing academics as the majority have turned to the banking sector as a context for their research. Indeed, a review of past papers in the Journal of Financial Services Marketing (JFSM) reveals that the category with the highest number of papers published is banking and, by comparison, few fall into the other financial services categories, including general insurance. This is somewhat surprising given the Journal's stated scope of welcoming marketing papers on banking services, pension plans, insurance, saving schemes, investment finance, personal finance, mortgages and credit and debit cards.

This paper seeks to address this imbalance and calls for researchers to consider general insurance as a context for their research. As insurance can be a complex and an often misunderstood market 
(Kunreuther, Pauly \& McMorrow, 2013), this paper will first define what constitutes general insurance and then detail how general insurance differs practically and theoretically from other financial services. In so doing, the need for research that specifically considers general insurance will be established. The paper will then review papers published to-date within the JFSM on general insurance. This will provide a benchmark of past work upon which future researchers can build. The paper will then turn its attention to the research needs of the general insurance industry going forward. A review of secondary published market reports, industry commentary and other publications is used to identify the challenges facing general insurance now and in the future as we look ahead to the next twenty years. Finally the paper concludes by issuing a call to financial services marketing researchers to undertake research in 5 key areas of general insurance marketing.

\section{General insurance and the financial services market}

Today the financial services industry comprises a wide range of financial institutions offering an array of products and services. In 1995, when the first issue of the JFSM was published, the financial services market was simply structured. In the main, a limited number of financial institutions were organised on the basis of the product(s) they provided to consumers. For example, in the UK banks concentrated on current accounts, building societies on mortgage and saving products, and insurance companies, insurance. Following deregulation in the late 1980s and growing competition within the marketplace, this clear differentiation by product line began to change. Today financial institutions are no longer tied solely to their original narrow product range. Banks and building societies offer general insurance to their customers and new entrants from the retail and other sectors also sell insurance. General insurance is now both a type of financial institution and, for others, a product within their wider portfolios.

Insurance is however a complex and fragmented sector. Ennew and Waite $(2007, \mathrm{p} 35)$ identified 5 different types of insurance, namely, life, general, composite, health and Lloyds syndicates. Details of each can be found in Table 1. In brief, general insurance includes personal insurance for 
individuals (e.g. motor, home, travel, and pet) as well as commercial insurance for businesses (e.g. liability, property, business interruption). Composites offer both life and general insurance. Although health insurance is often provided by a separate specialist health insurer, permanent health policies are available from general insurers. In addition, Lloyds of London provide general insurance products, albeit for more specialist risks. Ennew and Sekhon (2007) identified a further category within insurance: brokers and advisers, representing the intermediaries who operate in the general and life markets respectively. However, other forms of insurance and organisations exist, including reinsurance; Takaful (Islamic insurance); and the allied professions of, for example, loss adjusters (see Table 1 for further details). Insurance today is also provided by a wide array of organisations whose core business was (and may remain) outside financial services. Some now operate as general insurers, whereas others are essentially an intermediary, exploiting a strong brand to provide insurance products to their customers (for examples, see Brophy, 2015; Worthington, 2014; and Waite, 2001). As a direct result, the market today is significantly more complex and competitive than it was 20 years ago.

\section{Insurance is different}

Insurance differs in its purpose and nature from other financial services and, in particular, from banking. First, its purpose is unique. Insurance is a risk transfer mechanism whereby an individual can reduce the negative financial consequences of an uncertain future event (Trowbridge, 1975). Essentially, the consumer is purchasing peace of mind that in the event of an insured loss they will be indemnified, i.e. returned to the financial position they were in prior to the loss. Insurance is therefore, one of the most intangible of all the financial services.

Second, not all customers understand or accept the purpose of insurance and, instead, view insurance as a form of investment. In the absence of a claim such customers feel regret, the 
insurance was not consumed and the purchase unnecessary (Kunreuther, Pauly \& McMorrow, 2013). This can result in dis-satisfaction and mistrust at best, or at worst, dysfunctional behaviour in the form of fraudulent claims as the customer attempts to 'consume' the product they purchased.

Third, general insurance can be compulsory by law or a necessary addition alongside another purchase. For example, motor insurance and employer's liability are compulsory by law in most, if not all, countries. Buildings insurance is usually necessary when a mortgage is taken to purchase a house to protect the asset. Insurance, is therefore not always desired per se, but is a means to satisfy other wants and needs (Ehrlich and Becker, 1972).

Fourth, insurance is normally an annually renewed contract. In the absence of a change to policy details or a claim, the policyholder therefore has little or no need to contact their insurance provider during the year and the insurer must generate opportunities to stay in touch and build a relationship. The annual renewal itself can also work to erode any early signs of loyalty as it focuses the consumer's attention on price and can trigger a search of the marketplace for a better deal. General insurance (excluding large commercial) is becoming a commoditised market where there is little difference in policy cover and the purchase is made on price. This contrasts strongly with other financial services sectors, in particular the UK banking sector, where initiatives such as the national switching service were introduced to enable and encourage customers to switch banks more easily, yet the actual number of customers switching remains proportionately low (Dunkley, 2015).

Finally, a wrong purchase can lead to underinsurance or no insurance. Peace of mind is misplaced and the shortfall in cover will not be known until a later date. Past studies suggest that underinsurance is due to a lack of awareness of the types of insurance available or required and/or an inability to calculate the correct level of insurance, e.g. the sum insured (IIB Insurance 2015). Complex products (Bond and Stone, 2004) and consumer apathy (Farquhar and Robson, 2014), characteristics shared by many financial services, also contribute to inappropriate purchases. 
The above differences are particularly pertinent for individuals and small business consumers. Larger businesses are most likely to employ an insurance specialist with commercial and technical skills (Sekhon and Kennington, 2000). In addition, due to the complex nature of larger commercial risks and the higher premium charged, the purchase process is likely to be longer with more interaction between the insurer and consumer (Beloucif et al 2004).

Insurance therefore differs both practically and theoretically from other financial services and in particular banking. Differences are both in the nature of the product and the interactions with the provider. For example, banking (and in particular a current account) is a fairly simple, standardised product; transactions (and therefore contact with the provider) are frequent, possibly daily; and the service continues year on year without the need to renew. Differences of this nature have an impact on consumer behaviour and the marketing of the respective financial services categories. In order to develop a greater understanding of marketing within a financial services context, it is therefore important that research is undertaken in the different categories to take account of these differences. Given the unique nature of insurance, and specifically general insurance, this paper calls for more research in this context to build on the limited work undertaken to-date.

\section{General Insurance and the JFSM}

The JFSM is a natural home for empirical papers on general insurance marketing. An on-line search of all available papers using common general insurance terms (i.e. insurance, insurer, broker, claims, and underwriting and excluding papers on life insurance) identified just 9 papers on general insurance in the JFSM. This equates to less than $3 \%$ of all papers published. A complete listing of the papers is presented in table 1. 
Table 1 JFSM general insurance papers

\begin{tabular}{|l|l|l|l|l|}
\hline Year & Insurance type & Country & Theme & Authors \\
\hline 2003 & New entrant & UK & $\begin{array}{l}\text { Staff Coaching. Staff } \\
\text { retention }\end{array}$ & $\begin{array}{l}\text { Edwards, K., Chisholm, } \\
\text { L., \& Smith, T }\end{array}$ \\
\hline 2004 & $\begin{array}{l}\text { General insurance } \\
\text { company }\end{array}$ & Thailand & $\begin{array}{l}\text { Salesforce. New service } \\
\text { Development }\end{array}$ & $\begin{array}{l}\text { Rajatanavin, R., \& } \\
\text { Speece, M }\end{array}$ \\
\hline 2004 & $\begin{array}{l}\text { Intermediary: } \\
\text { broker }\end{array}$ & UK & $\begin{array}{l}\text { B2B Broker/client } \\
\text { relationship }\end{array}$ & $\begin{array}{l}\text { Beloucif, A., Donaldson, } \\
\text { B., \& Kazanci, U }\end{array}$ \\
\hline 2004 & $\begin{array}{l}\text { General Insurance } \\
\text { insurance }\end{array}$ & Israel & $\begin{array}{l}\text { Price/demand revenue } \\
\text { optimisation }\end{array}$ & $\begin{array}{l}\text { Lymberopoulos, K., } \\
\text { Chaniotakis, I. E., \& } \\
\text { Soureli, M. }\end{array}$ \\
\hline 2004 & $\begin{array}{l}\text { General Insurance S., Dolberger, D. } \\
\text { \& Eckel, J. }\end{array}$ \\
\hline 2005 & $\begin{array}{l}\text { General insurance } \\
\text { company }\end{array}$ & UK & $\begin{array}{l}\text { Claims. Customer } \\
\text { retention }\end{array}$ & Bond, A., \& Stone, M \\
\hline 2012 & $\begin{array}{l}\text { Intermediary: } \\
\text { broker }\end{array}$ & UK & Financial reporting & $\begin{array}{l}\text { Mirshekary, S., Yaftian, } \\
\text { A. M., \& Cross, D. }\end{array}$ \\
\hline 2013 & $\begin{array}{l}\text { General Insurance } \\
\text { (motor) }\end{array}$ & UK & $\begin{array}{l}\text { Consumer loyalty. } \\
\text { Switching }\end{array}$ & Ali, N \\
\hline
\end{tabular}

A review of the papers in table 1 identified three common themes that link the majority of the papers: attracting and retaining staff; customer service; and customer loyalty/retention.

Edwards et al (2003) and Ali (2012) focused on the general insurance employee and examined internal marketing and employee coaching respectively. Edwards et al (2003) provided a case study on a coaching initiative at an insurance call centre, whereas Ali (2012) examined the different forms of internal marketing in a broker context. Edwards et al (2003) measured this in terms of customer complaints, which were found to fall following the implementation of the coaching programme. Ali (2012) linked internal marketing with customer orientation and examined the different ways in which communication takes place. Both studies highlight the importance of the employee in general insurance and the challenge of attracting, motivating and retaining staff. Underpinning each is the link between satisfied staff, customer orientation and satisfied customers.

Customer service is a theme that is also developed by Beloucif et al (2004) and Bond and Stone (2004). In one of the few studies in table 1 that is set in a B2B context, Beloucif et al (2004) 
examined the broker and business customer relationship and identified the factors important to customers in this relationship. Service quality was found to be important as clients wanted the best return on the premium they had paid (p340). However, effective communication and price were also found to have an impact. Effective communication was defined as the broker's willingness to provide as much relevant information as possible ( $\mathrm{p} 339$ ). The importance of information was also echoed by Bond and Stone (2004) in their study of the B2C motor insurance market. They highlight the problems of complex insurance products and the failure of customers to understand what they are buying. Bond and Stone (2004) conclude that this is leading to a breakdown in trust between the customer and insurance provider and call for insurers to provide more information so that consumers know exactly what they are buying. Beloucif (2004) and Lymberopoulos et al (2003) also highlight the role of trust in the insurance relationship. None however define what trust means or explore how trust can be built in a general insurance context.

Price, and its role in customer retention, is a factor that appears in several of the JFSM papers. Beloucif et al (2004) found it to be one of the main factors to influence consumer buying behaviour, alongside service. They attributed this to the timing the research was conducted as this study took place during a hardening market where premiums had risen at more than twice the rate of inflation. Beloucif et al (2004) suggested that different results may be found in a soft market where prices are falling. Bond and Stone (2004) also point to contextual factors that can impact the relative importance of price. They found that price became less important, vis-à-vis- reputation, following an insurance claim. Price was also explored in the JFSM by Krikler et al (2004) in their case study on a direct motor insurer where they used a price optimisation tool. Price is undoubtedly an important theme in general insurance research, however, given the contextual differences what appears to be missing is an understanding of what price means to consumers, or as Bond and Stone's paper observes customers know what they are paying but not what they are buying (Bond and Stone, 2004 p171). 
Despite the global nature of financial services and the many changes that have taken place within the general insurance sector, the majority of papers have focused on a relatively narrow area within in insurance. Over half are UK based and focus on the traditional general insurance financial institution, the mass market motor insurance product and the long standing intermediary - an insurance broker. Limitations of this nature were recognised by Beloucif et al (2004) who called for researchers to take account of different industries and time; and Rajatanavir and Speece (2004) who highlighted the need for researchers to examine how specific cultures and country context can have an impact on general insurance research. In addition, Beloucif et al (2004) also identified the need to take account of the impact of technology that has subsequently reshaped this sector. There does therefore exist a number of gaps in our understanding of marketing within a general insurance context and it is these that will be used to create a research agenda going forward.

\section{A general insurance research agenda}

The review of past papers published on general insurance in the JFSM has provided a foundation upon which future researchers can build. Several gaps were identified in the available literature and these now provide the basis for setting the future research agenda for the general insurance sector. Five areas within two broad themes have been identified. The first are trust, transparency/simplicity and technology. Taken together these areas have a direct impact on consumer perceptions of general insurance and their buying behaviour. Second, and in response to the past focus on mass audiences within general insurance (i.e. motor insurance), a call is made for further research in two emerging research segments: HNW and Takaful.

\section{Trust}

Trust has been identified as one of the greatest challenges for the insurance industry going forward (Blanc, 2012; Spencer, 2013). The importance of trust has already been well established in the financial services literature (see for example, Sekhon et al., 2014; Ennew et al, 2011). Trust is 
however known to be affected by a wide range of factors and differ by context. Trust in a general insurance context will therefore differ from trust in other financial services contexts, not least because insurance is more intangible than other financial services and consumption is often delayed until a later date when an insured loss occurs.

In the UK, the Trust index (Ennew and Sekhon, 2007), measured the level of trust consumers have in different financial services. General insurance was found to be rated higher in terms of trustworthiness than investment companies and life insurers, lower than building societies, banks and credit card providers and much lower than brokers. More recently, EY (2015) echoed these findings; insurance customers were found to have more trust in the banking sector.

EY (2015) point to some of the underlying reasons for this lack of trust in general insurance specifically. Consumers believe that insurance providers make the terms and conditions in their policies deliberately complicated; and that claims are not paid out fairly. Such findings are not only reminiscent of the miss-selling scandals that have plagued the financial services sector but also reflect the problems consumers generally have in understanding financial service products and the nature of the products they are purchasing, an issue which is addressed later.

The general insurance sector needs to rebuild trust with the public. The challenge here is the lack of touch-points and communication between customers and their insurance providers. Technology has exacerbated this problem, however for most consumers the single point of contact they have with their insurer has always been at renewal when consumers are asked to pay again for their service. Those who have a need to make a claim will also come into contact with their insurer. The claim is often described as the 'acid test' of insurance as it is at this point that the customer truly experiences the promise that they have purchased (Robson and Sekhon, 2011).This provides an opportunity for the insurer to perform well, to build a relationship with the customer and, at the same time, build trust. However, EY (2015) also found that trust needs to be considered in its reciprocal form as one third of respondents believe that insurance providers expect them to lie 
about a claim. The question here is not only how do insurers rebuild consumer trust, but also how do insurers demonstrate to their customers that they also value and trust them?

\section{Transparency and simplification}

It is well known that many consumers struggle to understand financial products and make a purchase decision (Bond and Stone, 2004). Insurance is not unique in this sense, however a poor decision can lead to policyholders being at best underinsured or at worst, uninsured (ABI, 2015; insurance Times, 2015). This lack of knowledge and understanding applies equally to individual consumers and small businesses (IIB Insurance 2015). Such outcomes reflect negatively on the insurance market, eroding trust and as a result the need for greater transparency and simplification of insurance products and processes has been identified by many (see for example, EY, 2015; CII, 2012)

Broadly construed, transparency is about making relevant information available to consumers (Schwarcz, 2013). Beloucif et al (2004) called for effective communication, i.e. a willingness to provide as much relevant information as possible. However, it is not the volume of information that is important -there is also a need for information to be provided in a format that is easy to understand.

Initiatives within the insurance sector, such as Made Simple, a central e-library of easy-tounderstand information aims to demystify some of the language and market literature around personal lines policies (Post Magazine, 2015). Alongside this, individual insurers have also reviewed their processes and simplify them (Blanc, 2012). However more empirical research is required in this area to better understand what consumers need. Insurance, as with most other financial services, is not only an industry characterised by a lack of consumer knowledge and experience - but also consumer apathy (Farquhar and Robson, 2014). Most individual consumers purchase motor, home and travel insurance - not because they are desired per se, but because they are legally required or 
necessary as part of another purchase. In the past most consumers delegated this process to a broker. As technology has introduced new comparison sites, the search and buying decision is now in the hands of the consumer who may not understand the full implications of the information they are entering and the decisions they are making. In order to answer the question on how to make general insurance transparent and simple, more research is required that draws on the psychology, behavioural economics and marketing domains.

\section{Technology}

As with other financial services categories, technology has had a significant impact on the general insurance sector. Technology has changed the way insurance is distributed and purchased with the introduction of comparison websites and blogging; it has changed the types of risks insured to include driverless cars to cyber risks; and has enabled underwriters to fine grain their pricing through the use of telematics and big data. On the one hand, technology has empowered buyers, but on the other it has widened the gap in the customer-insurer relationship by further removing the personal element in this relationship (CII 2012). Given the issues of trust already identified and the problems that product complexity present within this marketplace there is a need to strengthen relationships. The call for further research on technology in general insurance is not therefore about technology adoption or technology readiness but how technology can be used to simplify the product offer, improve customer understanding and build trust.

\section{HNW}

In contrast to the discussion on trust, transparency/simplification and technology, which focused more on the mass audiences of general insurance, we now turn our attention to two emerging and important market segments. First, the High Net Worth (HNW) and middle class sectors are one of the fastest growing markets in Asia Pacific and has been identified as an attractive market for 
general insurers (EY, 2015). HNW consumers require premium priced tailored products to protect their valuable physical assets.

HNWs are defined according to their liquid (or investible) assets and this should amount to US\$1million or equivalent (Beaverstock and Faulconbridge, 2013). This value typically excludes the primary residence, collectables, consumables and consumer durables (Beaverstock et al., 2013), all items which are central to a general insurance policy. Insurers therefore require a different basis on which to identify and segment the HNW market.

Regardless of definition, few studies have been conducted on HNW consumers in general and understanding of this key market segment remains ill-defined. In part this is due to the methodological and practical problems inherent in researching this market (Featherstone 2014 ). Access is an issue (Beaverstock 2004 et al), HNWs can be protective of their privacy and reluctant to share information about their lives. This makes them difficult to research. Research on HNW consumers to-date has tended to focus on the extent, nature, sources and impacts of their wealth (Marroun et al, 2014 ). Little is therefore known about their consumption behaviour. Studies conducted in the financial services sector have focused more on wealth management and not attitudes, expectations and behaviour with respect to insurance.

There is therefore a need to provide greater insight into this consumer segment, not only in South Asia where the HNW are a relatively new and growing market segment and where cultural factors will have an impact, but also in the wide, global general insurance market. The key question here is how do HNW's differ in their perception and behaviour with respect to general insurance and most importantly, are HNWs one global homogenous niche as suggested by Marroun et al (2014) or do their needs differ by country and culture? 


\section{Takaful}

Takaful is Islamic insurance based on Sharia principles and includes general insurance (both personal and commercial). Although Takaful has been in existence for several decades it has only gained momentum in the past 10 years or so (AM Best 2015). It is expected that the Takaful market will grow significantly and reach \$20 billion in 2017 (AM Best 2015).

This growth is attributed to two factors. First, the global Muslim population is large and growing. By 2030, Muslims are expected to make up more than a quarter of the global population. (Pew Forum, 2015). Second, the number of new entrants into the Takaful market is expected to grow thereby increasingly the supply of Takaful products. Takaful is currently well established in Malaysia and Saudi Arabia and the United Arab Emirates (UAE) is also becoming an important growth market. Others are also entering this market, including London which is looking to be a global Islamic centre alongside Kuala Lumpur and Dubai (Mankaby, 2015).

Mittelstaedt (2002) has already called for researchers to seek a better understanding of the relationship between religion and religious norms on the marketplace. Much work has been done on Islamic banking (see for example, Thambiah et al., 2011; Dusuki and Addullah, 2007; and Jabnoun and Khalifa 2005). Early work on Takaful is progressing along similar lines to work already conducted in the Islamic banking sector by profiling Takaful consumers and examining the role of religion in the choice of Takaful versus traditional general insurance. Such work provides a sound basis on which to build. However, there is a greater need to understand the role of religion in consumption decisions in greater detail. Why, for example, does religion influence some purchasing decisions and not others and what other factors influence the role and influence of religion? In addition, how does the role of religion in a Takaful purchase differ from other Halal purchase decisions and for other products and other religions?

\section{Conclusion}


This paper has reviewed work published to-date on general insurance in the JFSM. In so doing it has identified past themes and established the theoretical contributions made. Building on this review, five key areas: trust, transparency/simplicity, technology, HNW and Takaful were suggested as a research agenda going forward.

To-date the general insurance sector has been described as complex and often misunderstood and this may well be the reason why financial services marketing researchers have in the past chosen to base their research in the banking or other financial services categories. It is hoped that this paper will shed light on this sector, highlight its unique nature and encourage many more researchers to conduct their research in the global general insurance marketplace. 


\section{$\underline{\text { References }}$}

ABI (2015) Is your home underinsured? Available from www.abi.org.uk

Ali, N. (2012). An exploratory study into the implementation of internal marketing in small insurance brokers in the United Kingdom. Journal of Financial Services Marketing, 17(3), 242-254.

AMBest (2015) Takaful Operators Struggle with Growth and Profitability. Middle east - non-life and life special report. Market Review, April 13, 2015

Beaverstock, J. V., Faulconbridge, J. R., \& Hall, S. J. (2014). The Globalization of Executive Search: Professional Services Strategy and Dynamics in the Contemporary World (Vol. 59). Routledge.

Beaverstock, J. V. (2004). 'Managing across borders': knowledge management and expatriation in professional service legal firms. Journal of Economic Geography, 4(2), 157-179.

Blanc, A (2012) Responding to challenges in general insurance in Upon the door of every cottage...Protecting the public through general insurance. Chartered Insurance Institute.

Beloucif, A., Donaldson, B., \& Kazanci, U. (2004). Insurance broker-client relationships: An assessment of quality and duration. Journal of Financial Services Marketing, 8(4), 327-342.

Bond, A., \& Stone, M. (2004). How the automotive insurance claims experience affects customer retention. Journal of Financial Services Marketing, 9(2), 160-171.

Brophy, R. (2015). A collection of insurance brands: The story of RSA in Ireland. Cogent Business \& Management, 2(1), 1067567.

CII (2012) Upon the door of every cottage...Protecting the public through general insurance. Chartered Insurance Institute.

Dunkley, E. (2015) A million UK customers switched banks in 2014. January 22, 2015. Available from www.Ft.com

Dusuki, A. W. and Abdullah, N. I., (2007). Why do Malaysian customers patronise Islamic banks? International Journal of Bank Marketing, 25 (3), 142-160.

Edwards, K., Chisholm, L., \& Smith, T. (2003). Craving for Coaching: a case study from Kwik-Fit insurance services. Journal of Financial Services Marketing, 8(2), 167-173.

Ehrlich, I., \& Becker, G. S. (1972). Market insurance, self-insurance, and self-protection. The Journal of Political Economy, 623-648.

Ennew, C and Waite, N (2007) Financial Services Marketing: An international guide to principles and practice. Routledge.

Ennew, C., Kharouf, H. and Sekhon, H. (2011) Trust in UK financial services: A longitudinal analysis. Journal of Financial Services Marketing 16, 65-75. 
Ennew, C., \& Sekhon, H. (2007). Measuring trust in financial services: The trust index. Consumer Policy Review, 17(2), 62

EY (2015) 2015 Global insurance outlook. Ernest and Yong. Available from www.ey.com

Farquhar, J and Robson, J . (2014). A Brave New World: Branding in Financial Services.

In T. Harrison and H. Estelami (eds.) Routledge Companion to Financial Services Marketing, Abington: Routledge.

Featherstone, M. (2014). The Rich and the Super-rich: Mobility, Consumption and Luxury Lifestyles. Consumer Culture, Modernity and Identity, 1

IIB insurance (2015) The Dangers of Being Underinsured. Independent insurance bureau Itd. Available from www.iibinsurance.co.uk.

Insurance Times (2015) Underinsurance is a business problem but a broker opportunity. Available from www.insurancetimes.co.uk

Jabnoun, N, and Khalifa, A.,(2005), A customized measure of service quality in the UAE, Managing Service Quality, 15 (4), 374-388,

Krikler, S., Dolberger, D,. \& Eckel, J. (2004) Method and tools for insurance price and revenue optimisation. Journal of Financial Services Marketing. 9 68-79

Kunreuther, H. C., Pauly, M. V., \& McMorrow, S. (2013). Insurance and behavioral economics: improving decisions in the most misunderstood industry. Cambridge University Press.

Lymberopoulos, K., Chaniotakis, I. E., \& Soureli, M. (2004). Opportunities for banks to cross-sell insurance products in Greece. Journal of Financial Services Marketing, 9(1), 34-48.

Marroun, S., Wilkinson, I., \& Young, L. Researching Consumer Behaviour at the Top of the Pyramid: Cultures of Consumption of the Super Rich. Australian New Zealand Marketing Academy Annual Conference, Griffith

Market Line (2015) Global non-life insurance. MarketLine Industry Profile. February 2015.

Datamonitor.

Mankaby, M. (2015) London - a global takaful centre. Global reinsurance. 20 August 2015. Available from www.globalreinsurance.com

Mirshekary, S., Yaftian, A. M., \& Cross, D. (2005). Australian corporate collapse: The case of HIH Insurance. Journal of Financial Services Marketing, 9(3), 249-258.

Middelstaedt, J. D. (2002)A framework for understadning the relationships between religion and markets. Journal of Macromarketing. 22(1) 6-8.

Pew Forum (2015) The Future of World Religions: Population Growth Projections, 2010-2050 Available from www.pewforum.org

Post Magazine (2015) Trust insurance campaign: A thirst for knowledge. Available from Insurance hound at www.insurancehound.co.uk 
Rajatanavin, R., \& Speece, M. (2004). The sales force as an information transfer mechanism for new service development in the Thai insurance industry. Journal of Financial Services Marketing, 8(3), 244-258.

Robson J. \& Sekhon Y. (2011) Addressing the research needs of the Insurance sector. International Journal of Bank Marketing special ediition on Insurance. 29 (7), 512-516.

Schwarcz, D. (2013). Transparency Opaque: Understanding the Lack of Transparency in Insurance Consumer Protection. UCLA L. Rev., 61, 394.

Sekhon, H., \& Kennington, C. (2001). Buyer seller relationships in the UK insurance market: Is this the key competitive advantage? Journal of Financial Services Marketing, 5(3), 207-214.

Spencer, R. (2013) General Insurance in the Twenty-First Century: Meeting the Challenges. The Chartered Insurance Institute Thinkpiece No. 94 May 2013

Taylor, S.A. (2013) Affect and marketing stimuli in consumer loyalty decisions to automobile insurers Journal of Financial Services Marketing 18, 4-16 (March 2013)

Thambiah, S., Malarvizhi, C., and Ismail, H. (2011). Islamic retail banking adoption: A conceptual framework. Australian Journal of Basic And Applied Sciences, 5(12), 649-657.

Trowbridge, C.L. (1975) Insurance as a transfer mechanism. The Journal of Risk and Insurance, Vol. 42, No. 1 (Mar., 1975), pp. 1-15

Waite, N. (2001) "New entrants in the financial services sector: the case of Kwik-Fit insurance services", International Journal of Bank Marketing, Vol. 19 Iss: 5, pp.213 - 216

Worthington, S. (2014). 'Challenger banks': Are they for real? In T. Harrison and H. Estelami (eds.) Routledge Companion to Financial Services Marketing, Abington: Routledge. 
Table 1: The UK General Insurance marketplace

\begin{tabular}{|l|l|}
\hline Insurance Type & Scope and products \\
\hline Life & Insures the life of a person, or group of people, for loss of income on death. \\
\hline General & $\begin{array}{l}\text { Divided into personal, commercial and London market. Personal insurance } \\
\text { covers private individuals e.g. motor, home, travel, accident and pet. } \\
\text { Commercial insurance covers businesses e.g. property, liability business } \\
\text { interruption, cyber, motor fleet etc. } \\
\text { Also known as non-life or property and casualty. }\end{array}$ \\
\hline London Market & $\begin{array}{l}\text { Located in the City of London and insures specialist, mainly commercial, } \\
\text { risks. Includes Lloyds. }\end{array}$ \\
\hline Composite & A combination of Life and General insurance \\
\hline Health & $\begin{array}{l}\text { Covers the cost of medical services in the event of sickness or accident. Can } \\
\text { be provided by specialist health insurers. Permanent health insurance is also } \\
\text { provided by general insurers and critical illness by life insurers }\end{array}$ \\
\hline Lloyds & $\begin{array}{l}\text { Specialist market for unusual risks in casualty, property, marine, energy, } \\
\text { motor, aviation and reinsurance. See London market }\end{array}$ \\
\hline Reinsurance & $\begin{array}{l}\text { Provides insurance for other insurance companies to cover a share of the } \\
\text { risk. }\end{array}$ \\
\hline Takaful & $\begin{array}{l}\text { Islamic insurance based on religious (Sharia) principles. Includes general and } \\
\text { family insurance. }\end{array}$ \\
\hline $\begin{array}{l}\text { Risk } \\
\text { Management }\end{array}$ & $\begin{array}{l}\text { Manages risk in organisations for insurance, business continuity, health and } \\
\text { safety, corporate governance, engineering, planning and financial services. }\end{array}$ \\
\hline Loss adjusters & $\begin{array}{l}\text { In the event of an insured loss, they advise both the insurance company and } \\
\text { the policyholder on repair and replacement. }\end{array}$ \\
\hline Broker & General insurance intermediary. \\
\hline Aggregator & $\begin{array}{l}\text { An on-line search facility providing customers with comparative insurance } \\
\text { quotes. }\end{array}$ \\
\hline Adviser & Life insurance intermediary. \\
\hline
\end{tabular}

